ISSN: 1907-9931 (print), 2476-9991 (online)

\title{
STUDI KONDISI HIDROLOGIS SEBAGAI LOKASI PENEMPATAN TERUMBU BUATAN DI PERAIRAN TANJUNG BENOA BALI
}

\author{
STUDY OF HIDROLOGICAL CONDITION FOR ARTIFICIAL REEF LOCATION \\ IN TANJUNG BENOA BALI
}

\author{
Abd. Rahman As-Syakur, Dwi Budi Wiyanto* \\ Program Studi IImu Kelautan, Fakultas Kelautan dan Perikanan, Universitas Udayana \\ Kampus Bukit Jimbaran, Gedung FKP Universitas Udayana, Bali, Indonesia \\ Corresponding author e-mail: wiyanto_marine@yahoo.com \\ Received: March 28, 2016/Accepted: March 31, 2016
}

\begin{abstract}
One of the tourism which was demanded by the tourists are underwater activity, namely scuba diving and seawalker, where the main target underwater tourism activities is the beauty of the underwater in the form of coral and reef fish. The purpose of this study is to determine the hydrological condition of artificial reefs in Tanjung Benoa, Bali. The method used in determining the location is a purposive sampling method. Sampling was carried out in three (3) stations and taken randomly in the study site (Tanjung Benoa). Measurement of hydrological conditions include the temperature, salinity, water clarity, current, depth, turbidity, TSS, DO, Nitrate, Phosphate. Hydrological conditions measurements carried out in situ (direct) and in laboratory. Data was analyzed by descriptive qualitative by comparing the quality of water based on the Ministry of the Environment Decree No. 51 of 2004 on Sea Water Quality Standard. Based on the results of hydrological conditions measurements, conditions of environmental parameters are still within the tolerance limit for the growth of marine biota. The basic conditions of the waters is not suitable for the placement of artificial reefs, this is because the substrate is muddy sand, where the basic conditions of these waters will submerge artificial reef into the sand.
\end{abstract}

Keywords: artificial reef, hidrological condition, Tanjung Benoa

\section{ABSTRAK}

Salah satu wisata yang sangat diminati oleh para wisatawan adalah wisata bawah air, yaitu scuba diving dan seawalker, dimana dalam kegiatan wisata bawah air yang menjadi target utama yaitu keindahan bawah air berupa terumbu karang dan ikan karang. Tujuan penelitian ini yaitu untuk mengetahui kondisi hidrologis terumbu karang buatan di Tanjung Benoa-Bali. Metode yang digunakan dalam penentuan lokasi sampling adalah metode sampling pertimbangan, yaitu metode pengambilan lokasi dan sampel didasarkan atas adanya tujuan tertentu dengan berbagai pertimbangan. Pengambilan sampel dilakukan di 3 (tiga) stasiun yang diambil secara acak di lokasi penelitian (Tanjung Benoa). Pengukuran kondisi hidrologis meliputi suhu, salinitas, kecerahan, kecepatan arus, kedalaman, kekeruhan, TSS, DO, Nitrat, Fosfat. Pengukuran kondisi hidrologis dilakukan secara insitu (langsung) dan pengujian skala laboratorium. Data di analisis secara diskriptif kualitatif dengan membandingkan kualitas air berdasarkan Keputusan Menteri Negara Lingkungan Hidup Nomor 51 Tahun 2004 Tentang Baku Mutu Air Laut. Berdasarkan hasil pengukuran kondisi hidrologis, kondisi parameter lingkungan masih dalam batas toleransi untuk pertumbuhan biota laut. Kondisi dasar perairan sangat tidak cocok untuk penempatan terumbu karang buatan (artificial reef), hal ini dikarenakan substrat dasar perairan yaitu pasir berlumpur, dimana kondisi dasar perairan tersebut akan menenggelamkan terumbu karang buatan (artificial reef) kedalam pasir.

Kata Kunci: kondisi hidrologis, terumbu buatan, Tanjung Benoa 


\section{PENDAHULUAN}

Sebagai salah satu ekosistem pesisir, hutan mangrove Tanjung Benoa merupakan tempat wisata di Bali yang terkenal akan pantainya. Tempat ini juga merupakan surganya wahana air seperti banana boat, scuba diving, parasailing, rolling donut, seawalker, flying fish. Pantai Tanjung Benoa memiliki laut yang aman, nyaman dan indah. Salah satu wisata yang sangat diminati oleh para wisatawan adalah wisata bawah air, yaitu scuba diving dan seawalker, dimana dalam kegiatan wisata bawah air yang menjadi target utama yaitu keindahan bawah air berupa terumbu karang dan ikan karang.

Terumbu karang adalah ekosistem yang dinamis dan terintegrasi dengan bahan penyusun mineral yang disumbangkan oleh hewan dan tanaman. Karena adanya unsur-unsur seperti ini terumbu karang menjadi suatu ekosistem dengan keragaman dan kompleksitas yang tinggi. Kondisi seputar lingkungan yang ada juga dapat membuat terumbu karang menjadi rapuh dan cepat rusak, karena karang tumbuh dengan baik didekat permukaan air laut yang hangat dan dekat dengan batas-batas daratan. Karenanya perubahan-perubahan dalam kondisi lingkungan di laut, udara atau daratan yang berinteraksi dengan laut memungkinkan untuk mempengaruhi kehidupan ekosistem karang (Smith and Buddemeier, 1992; Wilkinson and Buddemeier, 1994).

Pertumbuhan dan perkembangan karang berkaitan erat dengan Zooxanthellae. Karang mendapat zat-zat makanan dan oksigen $\left(\mathrm{O}_{2}\right)$ sebagai hasil fotosintesis dan sebaliknya Zooxanthellae mendapat perlindungan, zat hara dan karbondioksida $\left(\mathrm{CO}_{2}\right)$. Melalui laju pertumbuhan karang, maka dapat diketahui kondisi lingkungannya, karena laju pertumbuhan merupakan salah satu bentuk respon terhadap lingkungan. Laju pertumbuhan karang sangat berguna untuk berbagai kepentingan, seperti untuk kepentingan studi biologi yaitu untuk mengetahui kecepatan tumbuh karang dan untuk studi ekologi yaitu untuk mengetahui kondisi optimum pertumbuhan karang (Buddemeier and Kinzie, 1976 dalam Insafitri dan Nugraha, 2006). Untuk itu studi tentang kondisi hidrologis untuk terumbu karang buatan atau artificial reef sangatlah penting dalam kontribusi perkembangan IPTEK kelautan.

\section{MATERI DAN METODE}

Metode yang digunakan dalam penelitian ini adalah sample survey method atau survey di lapangan. Sampel survey method adalah pengambilan data dengan cara mencatat data mengenai situasi dan kejadian pada waktu dan tempat serta populasi yang terbatas, sehingga memberikan gambaran tentang situasi dan kondisi lokal (Hadi, 1986). Metode survey merupakan metode yang cenderung untuk meneliti sejumlah kecil variable pada unit sampel yang besar. Metode yang digunakan dalam penentuan lokasi sampling adalah metode sampling pertimbangan, yaitu metode pengambilan lokasi dan sampel didasarkan atas adanya tujuan tertentu dengan berbagai pertimbangan (Arikunto, 1993). Pengambilan sample dilakukan di 3 (tiga) stasiun yang diambil secara acak dilokasi penelitian.

\section{Pengukuran Kualitas Perairan}

Pengukuran kondisi hidrologis meliputi suhu, salinitas, kecerahan, kecepatan arus, kedalaman. Pengukuran kondisi hidrologis dilakukan secara insitu (langsung) dan pengujian skala laboratorium. Analisa data di analisis secara diskriptif kualitatif dengan membandingkan kualitas air berdasarkan Keputusan Menteri Negara Lingkungan Hidup Nomor 51 Tahun 2004 Tentang Baku Mutu Air Laut.

\section{HASIL DAN PEMBAHASAN}

Pengamatan kualitas air dilakukan meliputi aspek kualitas fisika dan kimia. Pentingnya informasi kualitas air ini ini berkaitan erat dengan tempat ruang gerak dan hidup ikan, udang, biota lainnya serta jasad-jasad makanannya. Berkaitan dengan hal tersebut, mutu air menjadi salah satu dasar pertimbangan dalam menentukan tingkat keseuaian lahan, serta sebagai dasar acuan dalam pemantauan lingkungan laut secara teratur berikutnya. Secara umum lokasi penelitian masih dalam batas toleransi sesuai dengan Keputusan Menteri Negara Lingkungan Hidup Tahun 2004 
tentang Baku Mutu Air Laut Untuk Biota Laut. Berdasarkan hasil penelitian, kualitas perairan di Tanjung Benoa masih layak untuk pertumbuhan terumbu karang. Sampel kualitas perairan diambil disekitar area wisata air, yaitu disisi utara dan selatan Tanjung Benoa. Lokasi pengukuran kualitas perairan ditentukan secara acak sebanyak 3 stasiun.

Tabel 1. Hasil pengukuran kualitas air di perairan Tanjung Benoa

\begin{tabular}{|c|c|c|c|c|c|c|c|c|c|c|c|}
\hline Titik & Latitude & Longitude & Depth $(\mathrm{M})$ & Kecerahan & Suhu $\left({ }^{\circ} \mathrm{C}\right)$ & Conductivity $(\boldsymbol{\mu N} / \mathrm{cm})$ & Salinity $(\mathrm{PPT})$ & Density $\left(\mathrm{kg} / \mathrm{m}^{3}\right)$ & Arus (cm/detik) & $\mathrm{pH}$ & $\mathrm{D} 0$ \\
\hline 1 & -8.756 .607 & 115.227 .345 & 6,8 & 6,8 & 24,1 & 51688,6 & 34,7 & 1023,4 & 0,7 & 8,00 & 8,4 \\
\hline 2 & $-8.758206^{\circ}$ & $115.228263^{\circ}$ & 6,5 & 6,5 & 24,7 & 51809,4 & 34,3 & 1023,0 & 0,8 & 7,98 & 8,3 \\
\hline 3 & $-8.758235^{\circ}$ & $115.230009^{\circ}$ & 6,6 & 6,6 & 24,4 & 51749,0 & 34,5 & 1023,2 & 1,3 & 8,04 & 8,7 \\
\hline
\end{tabular}

\section{Kedalaman Perairan}

Kedalaman berhubungan dengan iluminasi cahaya dan tingkat kecerahan perairan yang berperan dalam pertumbuhan karang. Semakin dalam laut akan semakin rendah kadar penembusan cahaya. Kebanyakan karang tumbuh dengan baik pada kedalaman kurang dari $25 \mathrm{~m}$. Pada kedalaman yang melebihi $70 \mathrm{~m}$, terumbu karang sukar ditemui (Levinton, 1982 dalam Agung, 2005). Terumbu karang juga dapat hidup pada kedalaman sampai $50 \mathrm{~m}$ dengan air yang sungguh-sungguh jernih. Hal ini berhubungan dengan proses penetrasi cahaya yang masuk ke perairan untuk fotosintesis.

Pengukuran kedalaman dilakukan pada saat air laut pasang, hal ini berhubungan dengan kondisi ketika air laut surut, sehingga akan berpengaruh terhadap artificial reef. Penempatan artificial reef disetiap lokasi harus memenuhi syarat dan ketentuan, salah satu yaitu tidak mengganggu jalur pelayaran. Berdasarkan hasil pengukuran di ketiga titik pengamatan masih dalam batas toleransi untuk pertumbuhan terumbu karang yaitu kurang dari 25 meter. Pada titik I kedalaman perairan yaitu 6,8 meter, pada titik II kedalaman perairan mencapai 6,5 meter sedangkan pada titik III kedalaman perairan mencapai 6,6 meter.

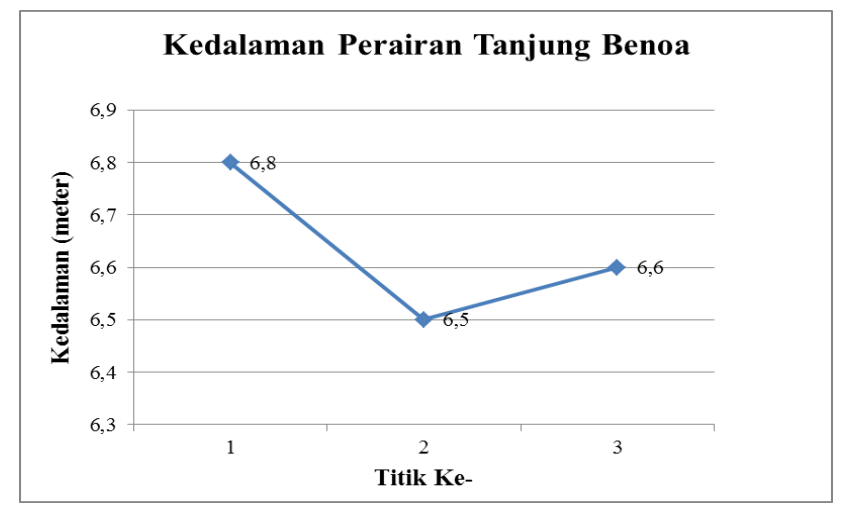

Gambar 1. Kondisi kedalaman perairan di Tanjung Benoa

\section{Kecerahan Perairan}

Kecerahan air merupakan ukuran kejernihan suatu perairan, semakin tinggi suatu kecerahan perairan semakin dalam cahaya menembus ke dalam air. Kecerahan air menentukan ketebalan lapisan produktif. Berkurangnya kecerahan air akan mengurangi kemampuan fotosintesis tumbuhan air, selain itu dapat pula mempengaruhi kegiatan fisiologi biota air, dalam hal ini bahanbahan yang masuk ke dalam suatu perairan terutama yang berupa suspensi dapat mengurangi kecerahan air (Effendi, 2000). Nilai kecerahan dinyatakan dalam satuan meter. Nilai ini sangat dipengaruhi oleh keadaan cuaca, waktu pengukuran, padatan tersuspensi dan kekeruhan serta ketelitian orang yang melakukan pengukuran. Tingkat kecerahan air dinyatakan dalam suatu nilai yang dikenal dengan kecerahan secchidisk (Effendi, 2000). 
ISSN: 1907-9931 (print), 2476-9991 (online)

Berdasarkan hasil pengukuran kecerahan perairan dengan menggunakan sechi disk terlihat bahwa angka kecerahan nilainya berkisar antara 6,5-6,8 meter. Kecerahan perairan menunjukkan kemampuan cahaya untuk menembus lapisan air pada kedalaman tertentu. Perairan yang memiliki nilai kecerahan tinggi pada waktu cuaca normal (cerah), memberikan suatu petunjuk atau indikasi rendahnya partikel yang terlarut dan tersuspensi dalam perairan. Hasil Pengamatan menunjukkan bahwa kecerahan di 3 (tiga) titik pengamatan masih dalam batas kecerahan untuk pertumbuhan terumbu karang, yaitu pada titik 1 kecerahan perairan 6,8 meter, sedangkan pada titik 2 kecerahan perairan yaitu 6,5 meter dan pada titik 3 6,6 meter. Kcerahan ketiga titik pengamatan masih dalam kategori layak untuk pertumbuhan biota laut terutama terumbu karang, hal ini sesuai dengan Keputusan Menteri Negara Lingkungan Hidup Tahun 2004 tentang Baku Mutu Air Laut untuk Biota Laut yaitu kecerahan perairan $>5$ meter.

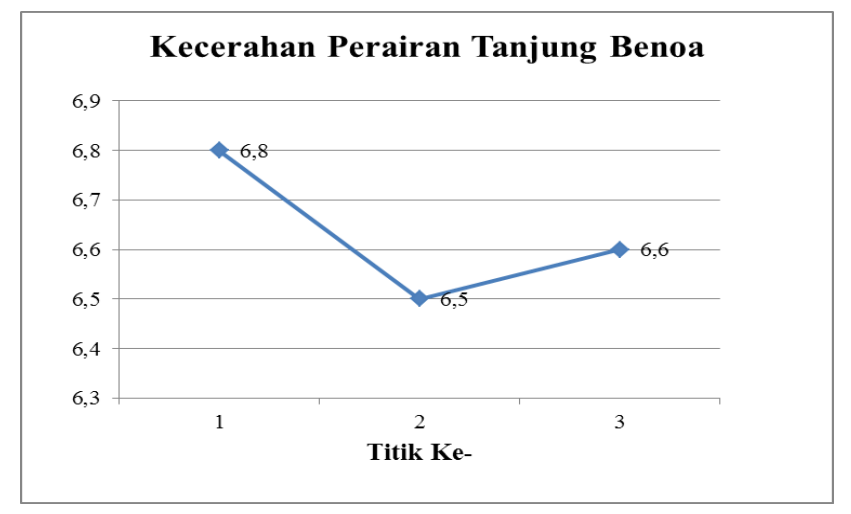

Gambar 2. Kondisi kecerahan di perairan Tanjung Benoa

\section{Suhu Perairan}

Kisaran suhu pada daerah tropis relatif stabil karena cahaya matahari lebih banyak mengenai daerah ekuator daripada daerah kutub. Hal ini dikarenakan cahaya matahari yang merambat melalui atmosfer banyak kehilangan panas sebelum cahaya tersebut mencapai kutub. Suhu di lautan kemungkinan berkisar antara $-1.87^{\circ} \mathrm{C}$ (titik beku air laut) di daerah kutub sampai maksimum sekitar $42^{\circ} \mathrm{C}$ di daerah perairan dangkal (Hutabarat dan Evans, 1986). Faktor yang memengaruhi suhu permukaan laut adalah letak ketinggian dari permukaan laut (Altituted), intensitas cahaya matahari yang diterima, musim, cuaca, kedalaman air, sirkulasi udara, dan penutupan awan (Hutabarat dan Evans, 1986).

Hasil pengamatan suhu perairan di Tanjung Benoa berkisar antara $24,1-24,7^{\circ} \mathrm{C}$. Secara umum dapat dikatakan bahwa suhu perairan lokasi penelitian adalah homogen, tidak terlihat stratifikasi berbeda antara kondisi suhu permukaan dan dasar. Nilai kisaran suhu perairan ini masih dalam batas ambang yang disarankan untuk perairan kehidupan normal biota laut. Struktur data suhu cenderung turun dengan bertambahnya kedalaman, namun demikian suhu air tidak menunjukkan gejala stratifikasi dan cukup baik dalam mendukung kehidupan ikan.

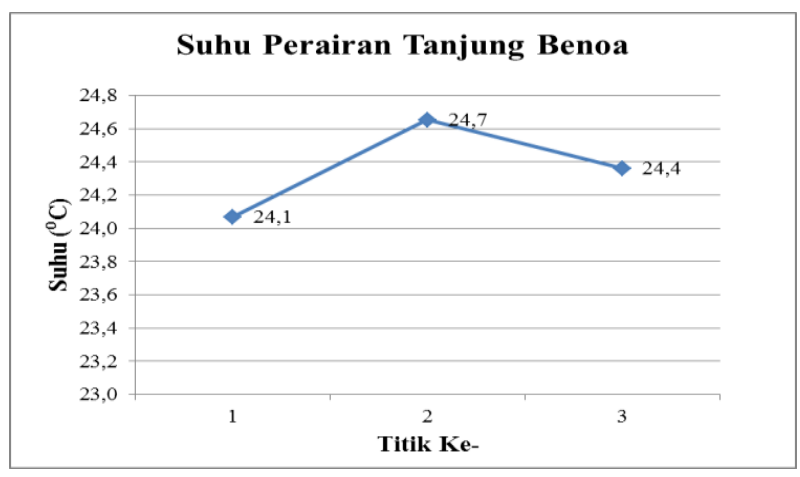

Gambar 3. Kondisi suhu di perairan Tanjung Benoa 


\section{Salinitas Perairan}

Salinitas adalah kadar garam terlarut dalam air. Salinitas merupakan sifat fisik-kimia suatu perairan. Salinitas laut dipengaruhi oleh berbagai faktor seperti sirkulasi air, penguapan, curah hujan dan aliran air sungai (Nontji. 1987). Hasil pengamatan salinitas di perairan Tanjung Benoa berkisar antara 34,3-34,7\%. Salinitas merupakan salah satu faktor penentu terhadap pertumbuhan dan kelangsungan hidup organisme laut. Kondisi salinitas di perairan Tanjung Benoa masih dalam batas toleransi untuk pertumbuhan biota laut, berdasarkan Keputusan Menteri Negara Lingkungan Hidup Tahun 2004 tentang baku mutu air laut untuk biota laut yaitu salinitas untuk biota laut yaitu berkisar antara 33-34 \% khususnya untuk terumbu karang.

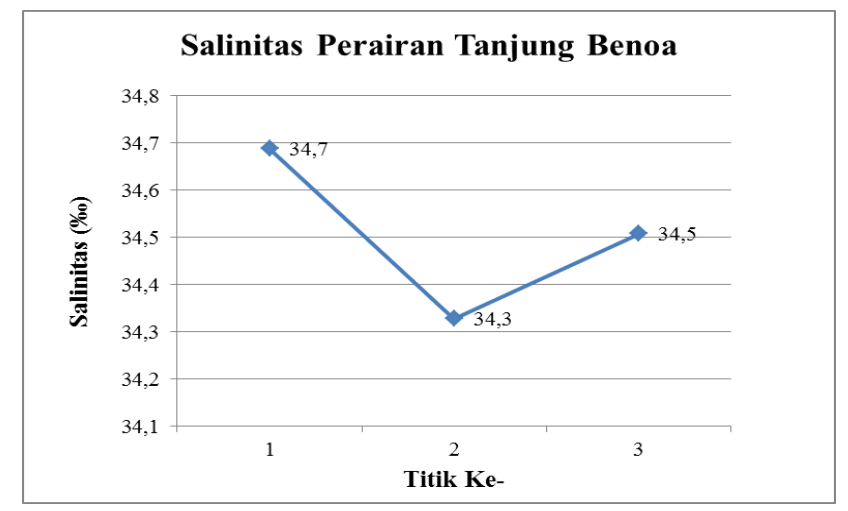

Gambar 4. Kondisi salinitas di perairan Tanjung Benoa

\section{Kecepatan Arus Perairan}

Faktor arus dapat berdampak baik atau buruk, bersifat positif apabila membawa nutrien dan bahan-bahan organik yang diperlukan oleh karang dan zooxanthellae, sedangkan bersifat negatif apabila menyebabkan sedimentasi di perairan terumbu karang dan menutupi permukaan karang sehingga berakibat pada kematian karang. Arus diperlukan dalam, proses pertumbuhan karang dalam hal menyuplai makanan berupa mikroplankton.

Arus juga berperan dalam proses pembersihan dari endapan-endapan material dan menyuplai oksigen yang berasal dari laut lepas. Sirkulasi arus sangat berperan penting dalam proses transfer energi. Pertumbuhan karang di perairan yang airnya selalu teraduk oleh arus dan ombak lebih baik dari pada di perairan yang tenang dan terlindung (Nontji, 1987).

Berdasarkan hasil pengukuran di Perairan Tanjung Benoa, pada titik I-III yaitu berskisar antara 0,7-1,3 meter/detik. Kecepatan arus pada ketiga lokasi penelitian masih dalam batas untuk pertumbuhan biota laut khususnya terumbu karang.

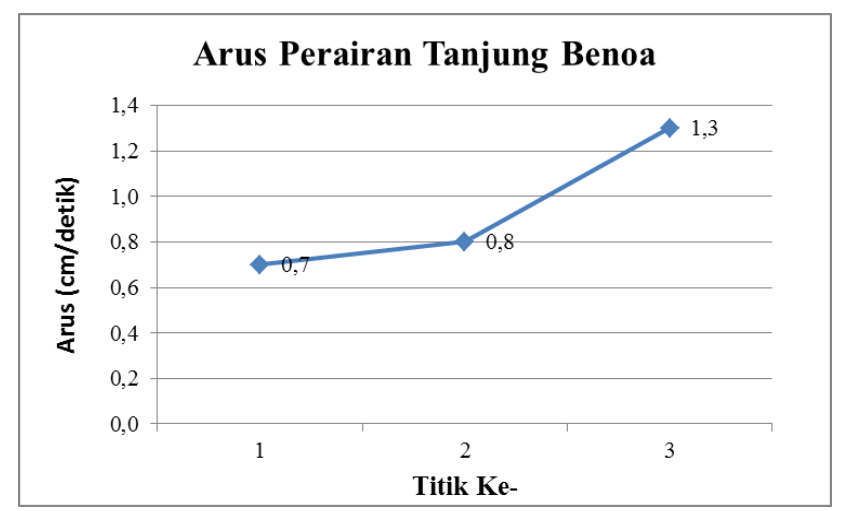

Gambar 5. Kondisi kecepatan arus di perairan Tanjung Benoa 


\section{Derajat Keasaman (pH) Perairan}

Derajat Keasaman $(\mathrm{pH})$ menunjukkan jumlah ion hidrogen dalam air laut yang dinyatakan dalam aktivitas hidrogen. Derajat keasaman ini mempunyai peranan penting terhadap proses-proses biologis dan kimia dalam perairan. Nilai $\mathrm{pH}$ air dapat memberikan gambaran tentang keseimbangan asam dan basa Derajat keasaman $(\mathrm{pH})$ disekitar lokasi penelitian berkiasar antara 7,98-8,04. $\mathrm{pH}$ perairan ini tergolong normal dan cukup produktif serta ideal untuk kehidupan biota perairan. Hal ini sesuai dengan dengan Keputusan Menteri Negara Lingkungan Hidup Tahun 2004 tentang baku mutu air laut untuk biota laut yaitu pH untuk biota laut berkisar antara 7-8,5.

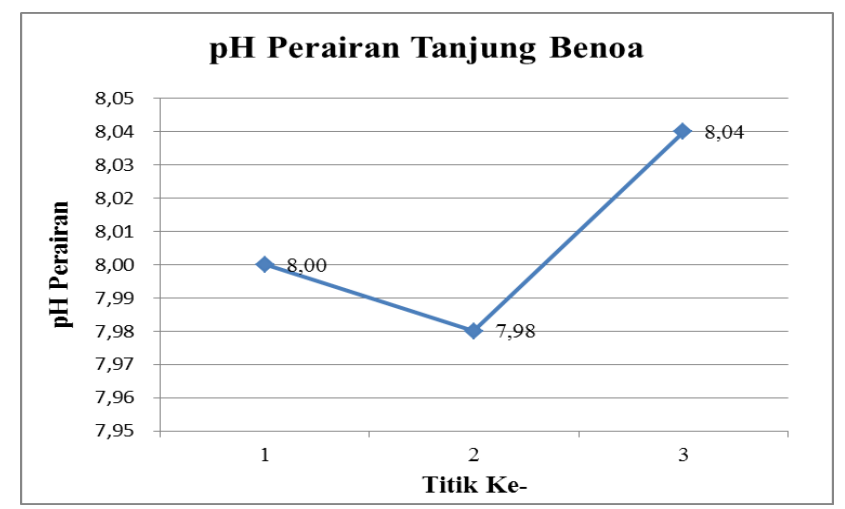

Gambar 6. Kondisi pH di perairan Tanjung Benoa

\section{Oksigen Terlarut (DO) Perairan}

Oksigen terlarut (DO) adalah jumlah oksigen terlarut dalam air yang berasal dari fotosintesa dan absorbsi atmosfer/udara. Oksigen terlarut di suatu perairan sangat berperan dalam proses penyerapan makanan oleh mahkluk hidup dalam air. Semakin banyak jumlah DO (dissolved oxygen) maka kualitas air semakin baik, jika kadar oksigen terlarut yang terlalu rendah akan menimbulkan bau yang tidak sedap akibat degradasi anaerobik yang mungkin saja terjadi. Secara umum kondisi oksigen terlarut di lokasi penelitian masih dalam batas toleransi untuk pertumbuhan biota laut yaitu berkisar antara 8,3-8,7 mg/l. Berdasarkan Keputusan Menteri Negara Lingkungan Hidup Tahun 2004 tentang baku mutu air laut untuk biota laut yaitu oksigen terlarut (DO) untuk biota laut yaitu $>5$.

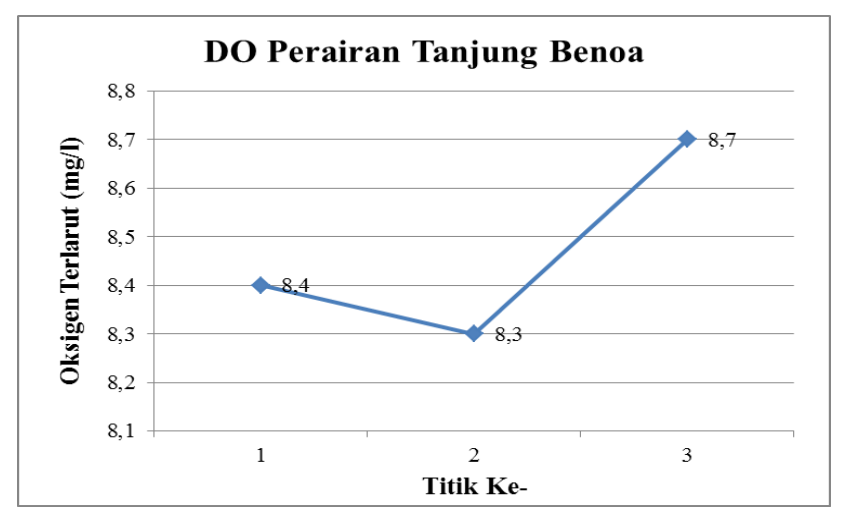

Gambar 7. Kondisi oksigen terlarut (DO) di perairan Tanjung Benoa

\section{Kondisi Dasar Perairan}

Pengambilan contoh sedimen dengan menggunakan sedimen grab. Hasil analisa butiran sedimen, menunjukkan sebaran sedimen perairan ini merupakan sedimen pasir lumpuran, Tidak adanya sungai di Perairan Tanjung Benoa yang mengindikasikan tidak ada pengaruh input dari darat sehingga memperlihatkan kondisi sebaran yang relatif homogen. Tipe dasar perairan yang 
baik untuk terumbu karang berpasir dengan kandungan lumpur yang rendah. Dari tiga titik yang diamati, tipe kondisi dasar semua pasir berlumpur dengan derajat kandungan pasir dan lumpur yang bervariasi. Kondisi dasar perairan dengan substrat pasir lumpur sangat tidak cocok untuk penempatan terumbu karang buatan, hal ini diduga karena dengan kondisi dasar perairan pasir berlumpur akan menenggelamkan terumbu karang buatan (artificial reef) itu sendiri kedalam pasir berlumpur. Lokasi yang sangat cocok untuk penenggelaman terumbu karang buatan (artificial reef) yaitu dasar perairan dengan substrat pecahan karang.

\section{KESIMPULAN DAN SARAN}

Berdasarkan hasil pengukuran kondisi hidrologis meliputi kedalaman, kecerahan, suhu, salinitas, kecepatan arus, pH dan DO kondisi parameter lingkungan tersebut masih dalam batas toleransi untuk pertumbuhan biota laut, kondisi parameter tersebut mengacu pada Keputusan Menteri Negara Lingkungan Hidup Tahun 2004 tentang baku mutu air laut untuk biota laut.

Kondisi dasar perairan merupakan faktor utama dalam penentuan lokasi penempatan terumbu karang buatan (artificial reef), pada penelitian ini kondisi dasar perairan sangat tidak cocok untuk penempatan terumbu karang buatan (artificial reef), hal ini dikarenakan substrat dasar perairan yaitu pasir berlumpur, dimana kondisi dasar perairan tersebut akan menenggelamkan terumbu karang buatan (artificial reef) kedalam pasir.

Saran dari kegiatan penelitian tentang Studi Kondisi Hidrologis untuk Artificial Reef di Perairan Tanjung Benoa-Bali ini, diharapkan dilakukan penelitian lanjutan, dengan memperbanyak titik penelitian sehingga dapat menemukan kondisi yang sesuai untuk penempatan terumbu karang buatan (artificial reef).

\section{UCAPAN TERIMA KASIH}

Penulis mengucapkan terima kasih kepada seluruh pihak yang telah memberikan bantuan dan fasilitas dalam penelitian ini

\section{DAFTAR PUSTAKA}

Agung, M. A. (2005). Studi densitas zooxanthellae pada karang masif Porites lutea dan Favia pallida di Perairan Desa Prancak Kecamatan Sepulu, Kabupaten Bangkalan. Praktek Kerja Lapang (PKL). Jurusan Ilmu Kelautan. Fakultas Pertanian. Universitas Trunojoyo. Madura.

Agung, M. A. (2006). Studi densitas zooxanthellae pada karang masif panca warna (Porites lutea) dan karang masif nanas pisah (Favia pallida) di Perairan Sepulu dan Klampis, Kabupaten Bangkalan. Skripsi. Jurusan IImu Kelautan. Fakultas Pertanian. Universitas Trunojoyo. Madura.

Anonymous (2002). Laporan akhir tahun tentang monitoring proyek pembuatan terumbu karang buatan di Kabupaten Bangkalan. Dinas Perikanan dan Kelautan Bangkalan

Anonymous (2003). Panduan pengenalan jenis-jenis karang hias yang diperdagangkan. Asosiasi Koral Kerang dan Ikan Hias Indonesia (AKKI).

Anonymous. (2005). Profil kecamatan kabupaten Bangkalan tahun 2005. BAPPEDA Kabupaten Bangkalan Kerjasama LPPM Universitas Trunojoyo.

Arikunto, S. (1993). Prosedur penelitian suatu pendekatan praktek. Rineka Cipta Jakarta.

Dahuri, R. (2003). Keanekaragaman hayati laut: aset pembangunan berkelanjutan Indonesia. Jakarta: PT. Gramedia

Effendi, H. (2000). Telaah kualitas air bagi pengelolaan sumber daya dan lingkungan perairan. Yogjakarta: Kanisius.

Hadi, S. (1986). Metodology research I. Yayasan Penerbit Fakultas Psikologi, UGM. Yogyakarta.

Hutabarat, S. (1985). Pengantar oseanografi. Jakarta : UI.

Hendrayana, P. (2003). Studi densitas zooxanthellae pada karang masif Porites lutea dan Favia pallida di Perairan Teluk Awur dan Pulau Panjang Jepara. Skripsi. Jurusan Ilmu Kelautan. Fakultas Perikanan dan IImu Kelautan. Universitas Diponegoro. Semarang. 
ISSN: 1907-9931 (print), 2476-9991 (online)

Insafitri, I., \& Nugraha, W. A. (2006). Laju Pertumbuhan Karang Porites lutea. ILMU KELAUTAN: Indonesian Journal of Marine Sciences, 11(1), 50-53.

Juniarta, N. (2002). Studi perubahan densitas zooxanthellae pada karang Acropora aspera dan Stylopora pistillata di Teluk Awur - Jepara. Skripsi. Jurusan IImu Kelautan. Fakultas Perikanan dan Ilmu Kelautan. Universitas Diponegoro. Semarang.

Nontji, A. (1984). Peranan zooxanthellae dalam ekosistem terumbu karang. Oseana, 9(3), $14 \mathrm{hlm}$.

Nontji, A. (1987). Laut nusantara. PT. Djambatan

Nybakken, J. W. (1992). Biologi laut: suatu pendekatan ekologis. Penerbit PT. Gramedia. Jakarta. 325-363.hlm.

Romimohtarto, K., \& Juwana, S. (1999). Biologi laut: ilmu pengetahuan tentang biologi laut. $\mathrm{P}_{3} \mathrm{O}-$ LIPI. Jakarta.

Suharsono (1996). Jenis-jenis karang yang umum di jumpai di Perairan Indonesia. $\mathrm{P}_{3} \mathrm{O}$-LIPI. Jakarta. $116 \mathrm{hlm}$.

Suharsono (1998). Kesadaran masyarakat tentang terumbu karang (kerusakan di Indonesia). Pusat Penelitian dan Pengembangan Oceanology-LIPI. Jakarta. $73 \mathrm{hlm}$.

Sukarno, Malikusworo, Mohammad, K. M., \& Prapto, D. (1981). Terumbu karang di Indonesia: sumber daya, permasalahan dan pengelolaannya. Proyek Penelitian Potensi Sumber Daya Alam Indonesia LON-LIPI, Jakarta.

Sukarno (1995). Metodologi penelitian terumbu karang. Materi Pendidikan dan Pelatihan Metodologi Penelitian Penentuan Kondisi Terumbu Karang. P3 $\mathrm{P}$-LIPI-UNDIP, Jepara, HIm 1-7.

Supriharyono (2000). Pengelolaan ekosistem terumbu karang. Penerbit Djambatan. Jakarta. 108 hlm.

Tomascik, T, Mah, A. J., Nontji, A., \& Moosa, M. K. (1997). The ecology of the Indonesian seas, part 1. Periplus Editions. Singapore. $642 \mathrm{pp}$.

Wagiyo, K., \& Radiarta (1995). Teknologi konservasi terumbu karang. Prosiding Seminar Nasional Pengelolaan Terumbu Karang. Panitia Program MBA Indonesia LIPI. 